\title{
Stress at Work among Electric Utility Workers
}

\author{
Maria Carmen MARTINEZ ${ }^{1 *}$ and Frida Marina FISCHER ${ }^{2}$
}

\author{
${ }^{1}$ Epidemiology Nucleus, Hospital Samaritano of São Paulo, Av. Conselheiro Brotero, 1505, 3o and. - cj. 32, \\ Higienópolis, 01232-010, São Paulo, SP, Brazil \\ ${ }^{2}$ Department of Environmental Health, School of Public Health, University of São Paulo, Av. Dr. Arnaldo, \\ 715, Cerqueira César, 01246-904, São Paulo, SP, Brazil
}

Received May 22, 2008 and accepted October 2, 2008

\begin{abstract}
In the last decades there was an increase in stress at work and its effects on workers' health. These issues are still little studied in the electric utility sector. This study aims to evaluate factors associated with stress at work and to verify its associations with health status among workers of an electric company in São Paulo State, Brazil. A cross-sectional study was conducted with 474 subjects (87.5\% of the eligible workers). Data were collected using self-reported questionnaires. A descriptive analysis, a multiple linear hierarchical regression analysis and a correlation analysis were performed. The majority of participants were males $(\mathbf{9 1 . 1 \% )}$ ) and the mean age was $37.5 \mathrm{yr}$. The mean score of stress level was 2.3 points (scale ranging from 1.0 to 5.0). Hierarchical multiple analyses showed that: regular practice of physical activities $(p=0.025)$ and individual monthly income $(\boldsymbol{p}=\mathbf{0 . 0 0 2})$ were inversely associated with stress level; BMI was marginally associated with the stress level $(p=0.074)$. The demographic characteristics were not associated with stress. Stress at work was significantly associated with physical and mental health status $(p<0.001)$. To improve health of electric utility workers, actions are suggested to decrease stress by remuneration and an appropriate practice of physical activity aiming reduction of BMI.
\end{abstract}

Key words: Occupational health, Stress at work, Psychosocial job factors, Workload, Mental health, Electric utility workers

\section{Introduction}

New work systems and organizational practices have generated outstanding changes in the characteristics of work, among these a transition from physical to mental tasks, which favors the incidence of stress related to work $^{1,2)}$. Stress at work, which results from an inadequate work design, bad work organization and/or work management interacting with individual characteristics has the potential to be detrimental to workers. In the last decades, stress at work has become a significant concern to public health in view of the damage it causes to the workers, companies and the society as a whole ${ }^{1,3)}$.

Work in the electric utility sector is designed for generation, transmission and distribution of electric power. It is characterized by exposure to multiple stressors: physical, biomechanical, biological and psychosocial factors ${ }^{4,5)}$. As examples, can be cited the risk of electric

*To whom correspondence should be addressed. shock, injury and trauma resulting from accidents during maintenance services of electrical systems, inadequate body posture, cognitive efforts in the interpretation of plants and sketches, traffic accidents, exposure to bad weather conditions, threat of unemployment, pressures of deadlines and responsibility for excellence at work ${ }^{4-7)}$.

In the last few decades, as a consequence of changes occurring in work relations and work processes, the mental load upon such workers has been intensified leading to an increase in stress at work, with possible negative consequences to the workers ${ }^{4,5,7)}$. Nevertheless, the literature approaching stress at work of this professional category is scarce; besides that, the large majority of publications is concentrated on matters related to exposure to electromagnetic fields ${ }^{8-10)}$.

The aims of the present study are to evaluate factors associated with stress at work and to verify if stress at work is associated with health status among electric utility workers. 


\section{Subject and Methods}

\section{Study design}

This cross-sectional study was carried out at a utility electric power company in the region of Campinas, State of São Paulo, Brazil, in 2005.

\section{Study population and sample}

The studied population comprised personnel from Electric Power Transmission, Electric Power Distribution and Administrative (Human Resources and Accounting) sectors. All 543 individuals working in the studied sectors for at least six months prior to this investigation were invited to participate. Those who were on sick leave, maternal leave or on vacation $(n=39)$ were not invited to join the study. A total of 474 workers $(87.3 \%$ of the eligible participants) agreed to fill out the questionnaire.

No significant differences ( $p>0.05$ ) were observed concerning sex, work sector and time on the job were observed among those who agreed to participate and those who didn't. Data for participants vs. non-participants were respectively, $91.1 \%$ and $94.2 \%$ males, $66.5 \%$ and $66.7 \%$ of the Electric Power Distribution Sector, and years on the job 13.0 (SD 7.5) and 12.2 (SD 6.8) yr; there was a statistically significant difference $(p=0.029)$ in relation to age: mean 37.5 (SD 8.0) and 39.7 (SD 7.2) yr.

\section{Research instruments}

A comprehensive self-report instrument including socio-demographic and occupational characteristics, as well as data on lifestyles and work stress was used. The first part of the instrument was composed by objective questions about socio-demographic and occupational characteristics: sex, age, marital status, schooling, time on the job, work sector, job title, shift work, job content and monthly income.

The second part of the instrument was about lifestyles and three questionnaires were included. The Baecke questionnaire investigates the habitual physical activity by means of 16 questions concerning occupational physical activities, physical exercises in leisure and locomotion physical activities, and it was validated for use in Brazil $^{11)}$. Cigarette smoking was estimated by the daily consumptions of cigarettes. It was used the Alcohol Use Disorders Identification Test (AUDIT), which assesses alcohol addiction, as recommended by the World Health Organization, and the categories were: never drink alcohol (0 points), alcohol consumption ( $\geq 1$ and $<8$ points), alcohol dependence ( $\geq 8$ points $)^{12}$. The Body Mass Index -BMI was used to assess the nutritional status, and the categories were: eutrophic $\left(<25.0 \mathrm{~kg} / \mathrm{m}^{2}\right)$, overweight $\left(\geq 25.0\right.$ and $\left.<30.0 \mathrm{~kg} / \mathrm{m}^{2}\right)$ and obesity $\left.\left(\geq 30.0 \mathrm{~kg} / \mathrm{m}^{2}\right)^{13}\right)$.

A third part of the survey included the questionnaire
Medical Outcomes Study 36 -Item Short Form Health Survey (SF-36). This is a comprehensive perception of health evaluation, and comprises 36 items included in eight scales: physical functioning, role-physical, bodily pain and general health which express physical health; vitality, social functioning, role-emotional and mental health which express mental health ${ }^{14)}$. Each scale scores 0 to 100 points and the used questionnaire was translated and validated for Portuguese language spoken in Brazil by Ciconelli $(1997)^{15)}$.

The fourth part of the questionnaire was the Work Stress Scale (WSS) which provides a general measure of stress at work based on 23 questions about different work psychosocial aspects. Each question presents a situation of exposure to stress at work, and answers portray the worker's perception about this situation in their daily work through a 5-points scale going from the best (1 -completely disagree) to the worst situation (5-completely agree). The means of the results generates a final score that ranges from 1.0 to 5.0 points. The WSS was built and validated for use in Brazil ${ }^{16)}$.

In this study population, the reliability of the questionnaires was assessed by the Cronbach's coefficient alpha and showed the following results: WSS: $\alpha=0.94$; Baecke's questionnaire $\alpha=0.66$; AUDIT questionnaire $\alpha=0.79$; for all SF-36 scales the results were $\alpha \geq 0.72$.

\section{Statistical analyses}

A descriptive analysis was performed by using means, standard deviations, minimum and maximum values of the scores attributed to continuous variables and ratios referring to categorical variables. The Kolmogorov-Smirnov test was performed to check adherence of the score of stress at work to normal distribution, thus determining the type of statistical tests to be performed. The association between stress at work and the continuous variables was initially tested by using Spearman's correlation coefficients (non-parametric variables) and Pearson's correlation coefficients (parametric variables); as for categorical variables, the Mann-Whitney and the Krüskal-Wallis tests were used. Finally, a hierarchical multiple linear regression analysis was conducted. A 5\% level of significance was used for all performed analyses.

The order of entry in the model was as follows: demographic features, lifestyles and occupational characteristics. The sociodemographic characteristics and lifestyles comprised the first and the second level of the hierarchical model respectively. Such option was based on a conceptual model whose purpose is to explain the process of stress at work which considers the individual characteristics as the process basis, as such characteristics may interact with work risk factors and may either worsen or soften their effects ${ }^{17)}$. The occupational characteristics have 
been incorporated into the third level because they may define the characteristics and qualities of the work conditions, thus influencing the level of stress ${ }^{1,18,19)}$.

The association between stress at work and the health status variables was tested by using Spearman's correlation coefficients.

\section{Ethical aspects}

The project was approved by the Ethics Committee of the School of Public Health of the University of São Paulo. It followed the principles of the Declaration of Helsinki issued by the World Medical Association. Workers participation was voluntary upon signature of a formal consent.

\section{Results}

\section{Descriptive statistics}

The categorical variables of socio-demographic, occupational and lifestyles features are shown in Table 1. Most participants were males $(91.1 \%)$, married or living with a partner $(75.1 \%)$, and the majority had high school $(64.8 \%)$ or College education $(26.8 \%)$. Mean age was 37.5 (SD 8.0) yr.

The majority worked in the Power Distribution Sector (66.5\%); $58.6 \%$ of the study population occupied job titles as distribution electricians and live line distribution electricians. The workers performed activities mainly during day shifts $(94.3 \%)$. Seventy-seven point eight of the studied workers performed miscellaneous jobs which involved physical and mental tasks. Monthly payment ranged from 640 to 1,750 USD in $94.1 \%$ of the studied population. Mean years on the job were 13.0 (SD 7.5).

The large majority (98.1\%) reported regular practice of physical activities, with the mean score of Baecke questionnaire reaching 8.5 points on a 15.0 -point scale. Regular tobacco users were $14.6 \%$, and $78.7 \%$ reported to consume alcoholic drinks; among those, $22.2 \%$ showed a result of AUDIT questionnaire suggesting alcohol dependence. Overweight or obesity prevailed among $59.7 \%$, and the mean of body mass index was 26.4 (SD 3.9) points.

The health dimensions that were assigned the highest scores were: physical functioning, role-physical, roleemotional and social functioning, scoring 82.4 points or above on a 100 -point scale (Table 2).

Stress at work showed an average of 2.3 points on a 5.0-point scale (SD 0.7). The psychosocial aspects of the work environment that represented the main sources of stress were: discrimination/favoritism at the workplace, poor appreciation by superiors, slim perspective of professional growth, lack of information on organizational decisions, and the way tasks were distributed (Table 3).
Analysis of associated factors with stress at work

The results of the association tests are shown in Tables 4 and 5. Factors closely associated with stress at work were marital status $(p=0.040)$; body mass index $(p=0.025)$; practice of physical activities $(0.044)$ and time on the job $(p=0.037)$.

The results of the hierarchical multiple linear regression model are shown in Table 6. The first level variables (socio-demographic) weren't associated with stress at work. At the second level (lifestyle variables), only the practice of physical activities was associated with stress at work $(p=0.025)$ - the more intense the practice of such activities, the lower the level of perceived stress at work. At the third level (occupational variables), only the monthly income showed a statistically significant association with stress $(p=0.002)$, - the higher the income, the lower the level of stress at work.

\section{Analysis of association between stress at work and health status}

The results of the association tests are shown in Table 7. In spite the correlations were low, the work stress showed statistically significant association with all physical and mental health dimensions $(p<0.0001)$, and the higher the stress level, the worse the health status.

\section{Discussion}

The level of stress in this studied working population was moderate and distinct variables were independently associated with stress at work. Also, we observed stress at work associated with all evaluated health dimensions.

The response rate for the present study was $87.5 \%$, thus above the $75.0 \%$ considered adequate ${ }^{20}$. The analysis of internal consistency showed that Baecke's questionnaire registered a Cronbach's alpha of 0.66. There isn't an ideal cut-off point to arbitrate Cronbach's alpha and, more important than judging its merit (good or bad), it is to assess the complexity of the phenomenon one intends to measure $^{21)}$. Considering that the practice of physical activities is relevant to the study and it is a factor too complex to be measured, we have decided to maintain it in the analysis.

\section{Characteristics of the studied population}

The studied population had some specific socio-demographic characteristics, such as its composition in terms of sex, age and income. Due to this fact, is difficult to compare results with other working groups. Regarding SF-36 dimensions, the study population reported good health status, all of them with $70 \%$ out of the maximum score levels.

As lifestyles is concerned this group of electric utility 
Table 1. Descriptive statistics of the study population, electric utility workers, São Paulo, 2005

\begin{tabular}{|c|c|c|c|}
\hline Variables & Class & № & $\%$ \\
\hline \multicolumn{4}{|c|}{ Sociodemographic features } \\
\hline \multirow[t]{2}{*}{ Sex } & Female & 42 & 8.9 \\
\hline & Male & 432 & 91.1 \\
\hline \multirow{3}{*}{$\begin{array}{l}\text { Marital } \\
\text { status }\end{array}$} & Married/Living with a partner & 356 & 75.1 \\
\hline & Single/Divorced/Widowed & 116 & 24.5 \\
\hline & Not informed & 2 & 0.4 \\
\hline \multirow[t]{3}{*}{ School level } & Fundamental school & 40 & 8.4 \\
\hline & High school & 307 & 64.8 \\
\hline & College & 127 & 26.8 \\
\hline \multicolumn{4}{|c|}{ Occupational features } \\
\hline \multirow[t]{3}{*}{ Work sector } & Administrative & 82 & 17.3 \\
\hline & Power Distribution & 315 & 66.5 \\
\hline & Power Transmission & 77 & 16.2 \\
\hline \multirow[t]{4}{*}{ Job title } & Administrative & 90 & 19.0 \\
\hline & Distribution leaders or technicians & 33 & 7.0 \\
\hline & Distribution electricians or live line electricians & 278 & 58.6 \\
\hline & Transmission electricians, live line electricians or technicians & 73 & 15.4 \\
\hline \multirow[t]{2}{*}{ Shift work } & Day & 447 & 94.3 \\
\hline & Night & 27 & 5.7 \\
\hline \multirow[t]{2}{*}{ Job content } & Mental & 105 & 22.2 \\
\hline & Mixed (mental and physical) & 369 & 77.8 \\
\hline Monthly & $<640$ & 28 & 5.9 \\
\hline income & $640-1,119$ & 218 & 46.0 \\
\hline \multirow[t]{4}{*}{ (U.S.dollars) } & $1,120-1,750$ & 143 & 30.2 \\
\hline & $1,751-2,560$ & 36 & 7.6 \\
\hline & $2,561-3,360$ & 34 & 7.2 \\
\hline & $>3,360$ & 15 & 3.2 \\
\hline \multicolumn{4}{|c|}{ Lifestyles } \\
\hline \multirow{2}{*}{$\begin{array}{l}\text { Physical } \\
\text { activity }\end{array}$} & Regular practice & 465 & 98.1 \\
\hline & Irregular or without practice & 9 & 1.9 \\
\hline \multirow[t]{5}{*}{ Smoking habits } & Never smoked & 301 & 63.6 \\
\hline & Former smoker & 103 & 21.8 \\
\hline & $<10$ cigarettes/day & 16 & 3.4 \\
\hline & 10 to 19 cigarettes/day & 21 & 4.4 \\
\hline & $\geq 20$ cigarettes/day & 32 & 6.8 \\
\hline Alcohol & Never drink alcohol (0) & 98 & 20.7 \\
\hline \multirow{3}{*}{$\begin{array}{l}\text { Consumption * } \\
\text { (points) }\end{array}$} & Alcohol consumption $(\geq 1$ and $<8$ ) & 268 & 56.5 \\
\hline & Alcohol dependence $(\geq 8)$ & 105 & 22.2 \\
\hline & Not informed & 3 & 0.6 \\
\hline \multirow{3}{*}{$\begin{array}{l}\text { Werght } \\
\left(\mathrm{kg} / \mathrm{m}^{2}\right)\end{array}$} & Eutrophic $(<25,0)$ & 191 & 40.3 \\
\hline & Overweight $(\geq 25,0$ and $<30,0)$ & 203 & 42.8 \\
\hline & Obesity $(\geq 30,0)$ & 80 & 16.9 \\
\hline Total & & 474 & 100.0 \\
\hline
\end{tabular}

*AUDIT questionnaire —categories.

**Body mass index —categories. 
Table 2. Health status among electric utility workers, São Paulo, 2005

\begin{tabular}{crc}
\hline Health dimension* & Mean & \multicolumn{1}{c}{ SD } \\
\hline \multicolumn{2}{c}{ Physical component } \\
Physical functioning & 91.2 & 13.3 \\
Role-physical & 88.3 & 24.4 \\
Bodily pain & 75.0 & 20.8 \\
General health & 80.7 & 16.1 \\
\hline Mental component & \\
Vitality & 72.8 & 17.0 \\
Social functioning & 82.4 & 20.2 \\
Role-emotional & 85.0 & 28.7 \\
Mental health & 76.6 & 17.1 \\
\hline
\end{tabular}

* SF-36 - score ranging from 0.0 to 100.0 points.

Table 3. Stress at work among electric utility workers, São Paulo, 2005

\begin{tabular}{lcc}
\hline \multicolumn{1}{c}{ Source of stress* } & Mean & SD \\
\hline Presence of discrimination/favoritism & 3.0 & 1.4 \\
Lack of appraisal & 2.8 & 1.3 \\
Poor professional growth perspectives & 2.8 & 1.2 \\
Lack of organizational information & 2.6 & 1.1 \\
Way tasks are distributed & 2.6 & 1.0 \\
Under-utilization of skills & 2.4 & 1.2 \\
Lack of control over work & 2.4 & 1.1 \\
Poor training & 2.4 & 1.1 \\
Lack of information on tasks to be performed & 2.4 & 1.0 \\
Boycott from supervisor & 2.3 & 1.2 \\
Rivalry at the work environment & 2.3 & 1.1 \\
Insufficient time to perform tasks & 2.3 & 1.1 \\
Confidence of supervisor in my work & 2.2 & 1.2 \\
Poor communication from supervisor & 2.2 & 1.1 \\
Assigned major responsibilities & 2.2 & 1.1 \\
Lack of autonomy at work & 2.2 & 1.0 \\
Role ambiguity & 2.2 & 1.0 \\
Ill-treated by supervisor & 2.1 & 1.3 \\
Poor communication among co-workers & 2.1 & 1.0 \\
Contradictory orders & 2.1 & 1.0 \\
Long work shifts & 2.0 & 1.0 \\
Feeling of isolation at work & 2.0 & 1.0 \\
Tasks beyond skills & 1.9 & 1.0 \\
\hline Stress at work (mean score) & 2.3 & 0.7 \\
\hline
\end{tabular}

* Work Stress Scale - score ranging from 0.0 to 5.0 points.

workers showed a satisfactory profile concerning the practice of physical exercise $(98.1 \%)$, however such practice lacked homogeneity in terms of frequency, type and intensity. The high prevalence of physical activity of this studied population can be explained by two factors: (1) there is a fitness center close to their workplaces and actions to encourage the physical practice in this company has been developed for some years, and (2) the job tasks require a good physical conditioning to meet the tasks demands, which may encourage to maintain an adequate functional ability.

It is well known that the abuse of alcohol causes serious damage to the employees, businesses and society ${ }^{22,23)}$. It was reported a high prevalence of drinking habits $(78.7 \%)$ and alcohol addiction $(22.2 \%)$ among the studied population. This alcohol consumption is not consistent with a favorable profile of high physical activity and health status of the studied population.

The study design does not allow casual relations, but during the data collection it was possible to raise a speculative hypothesis: this was a predominantly male and young population, with intense social life, and alcohol consumption is culturally valued as a positive behavior expressing masculinity and sociability. Alcohol consumption is a social act with defined in the context of each social group, and this is related to the cultural image of masculinity, socialization, competitiveness, achievement and self-esteem ${ }^{24-26)}$. As the study group is a young population this might explain why the negative effects of alcohol consumption still are not present ${ }^{23)}$. Another aspect of consideration is the healthy worker effect due to the study design.

The high prevalence of overweight and obesity was also not consistent with the regular practice of physical activity of the studied population. A possible explanation would be a methodological limitation as we used BMI as a measure of nutritional status. The BMI does not allow the distinction between fat mass and fat-free mass, mainly in men, and the practice of physical exercise can reduce the length of the waist without altering the value of $\mathrm{BMI}^{27,28)}$.

\section{Stress at work}

The assessment of work psychosocial factors showed that the major sources of stress were those related to difficulties concerning professional growth and appreciation. As for the global evaluation of work activities, perception of an intermediate level of stress at work was reported. This result is similar to the one obtained from a study using the same methodology to evaluate 237 employees working at a banking institution ${ }^{16)}$.

The reported level of stress at work can be considered moderate into the score, but must be taken into account because of its possible adverse impacts. Continuous exposure to adverse conditions may trigger backlashes in terms of morbidity, and may also compromise wellbeing, reduce productivity, and increase both absenteeism and dissatisfaction with work $^{1,2,19,29)}$. 
Table 4. Categorical variables associated with stress at work among electric utility workers, São Paulo, 2005

\begin{tabular}{|c|c|c|c|}
\hline Variables & Class & $\begin{array}{c}\text { Mean } \\
\text { (Std Deviation) }\end{array}$ & $p$ \\
\hline \multicolumn{4}{|c|}{ Sociodemographic features } \\
\hline \multirow[t]{2}{*}{ Sex } & Female & $2.20(0.66)$ & $0.298^{(\mathrm{M})}$ \\
\hline & Male & $2.33(0.73)$ & \\
\hline \multirow{2}{*}{$\begin{array}{l}\text { Marital } \\
\text { status }\end{array}$} & Married/Living with a partner & $2.35(0.73)$ & $0.040^{(\mathrm{M})}$ \\
\hline & Single/Divorced/Widowed & $2.20(0.66)$ & \\
\hline \multirow[t]{2}{*}{ School level } & College under graduation & $2.32(0.70)$ & $0.684^{(\mathrm{M})}$ \\
\hline & College graduation & $2.32(0.79)$ & \\
\hline \multicolumn{4}{|c|}{ Occupational features } \\
\hline \multirow[t]{3}{*}{ Work sector } & Administrative & $2.26(0.68)$ & $0.382^{(\mathrm{K})}$ \\
\hline & Power Distribution Sector & $2.32(0.73)$ & \\
\hline & Power Transmission Sector & $2.37(0.72)$ & \\
\hline \multirow[t]{4}{*}{ Job title } & Administrative & $2.28(0.71)$ & $0.590^{(\mathrm{K})}$ \\
\hline & Distribution Leaders or Technicians & $2.40(0.85)$ & \\
\hline & Distribution Electricians or Live Line Electricians & $2.31(0.72)$ & \\
\hline & Transmission Electricians, Live Line Electricians or Technicians & $2.38(0.70)$ & \\
\hline \multirow[t]{2}{*}{ Shift work } & Day & $2.31(0.72)$ & $0.214^{(\mathrm{K})}$ \\
\hline & Night & $2.46(0.76)$ & \\
\hline \multirow[t]{2}{*}{ Job content } & Mental & $2.32(0.76)$ & $0.553^{(\mathrm{M})}$ \\
\hline & Mixed (mental and physical) & $2.32(0.71)$ & \\
\hline \multirow{6}{*}{$\begin{array}{c}\text { Monthly } \\
\text { income } \\
\text { (U.S.dollars) }\end{array}$} & $<640$ USD & $2.18(0.85)$ & $0.234^{(\mathrm{K})}$ \\
\hline & $640-1,119$ USD & $2.38(0.67)$ & \\
\hline & $1,120-1,750$ USD & $2.29(0.72)$ & \\
\hline & $1,751-2,560$ USD & $2.31(0.84)$ & \\
\hline & 2,561-3,360 USD & $2.28(0.73)$ & \\
\hline & $>3,360$ USD & $2.12(0.90)$ & \\
\hline \multicolumn{4}{|c|}{ Lifestyles } \\
\hline \multirow{5}{*}{$\begin{array}{c}\text { Smoking } \\
\text { habits }\end{array}$} & Never smoked & $2.33(0.73)$ & $0.423^{(\mathrm{K})}$ \\
\hline & Used to smoke but quit & $2.27(0.75)$ & \\
\hline & $<10$ cigarettes/day & $2.13(0.55)$ & \\
\hline & 10 to 19 cigarettes/day & $2.43(0.57)$ & \\
\hline & $\geq 20$ cigarettes/day & $2.47(0.69)$ & \\
\hline
\end{tabular}

(M) = Mann-Whitney test.

${ }^{(\mathrm{K})}=$ Kruskal-Wallis test.

Table 5. Continuous variables associated with stress at work among electric utility workers, São Paulo, 2005

\begin{tabular}{|c|c|c|c|}
\hline Variables & $\mathrm{N}$ & $\mathrm{r}$ & $p$ \\
\hline \multicolumn{4}{|c|}{ Sociodemographic features } \\
\hline Age & 474 & 0.08 & $0.077^{(\mathrm{S})}$ \\
\hline \multicolumn{4}{|c|}{ Occupational features } \\
\hline Time on the job (years) & 474 & 0.12 & $0.012^{(\mathrm{S})}$ \\
\hline \multicolumn{4}{|c|}{ Lifestyles } \\
\hline Body mass index $\left(\mathrm{kg} / \mathrm{m}^{2}\right)^{*}$ & 474 & 0.10 & $0.025^{(\mathrm{S})}$ \\
\hline Alcohol consumption** & 471 & 0.09 & $0.061^{(\mathrm{S})}$ \\
\hline Physical activity*** & 474 & -0.09 & $0.044^{(\mathrm{P})}$ \\
\hline
\end{tabular}

*Body mass index - score.

**AUDIT questionnaire - score ranging from 0.0 to 40.0 points.

***Baecke questionnaire - score ranging from 0.0 to 15.0 points.

(S) = Spearman's correlation coefficients.

(P) $=$ Pearson's correlation coefficients.
Associated factors with stress at work

The multivariate analysis showed the practice of physical activities and income level as associated factors with the level of stress at work.

As mentioned, since the study design does not allow causal relationships, the association observed between the practice of a physical activity and stress at work may have two distinct interpretations. On one side, physical exercise triggers positive psychobiological changes leading to body mass control, maintenance of physical capacity and reduction of symptoms associated with depression and anxiety, thus increasing self esteem and reducing emotional reactions to stress ${ }^{30,31)}$. On the other side, stress at work may operate in an indirect way, affecting behaviors and life styles ${ }^{1,32)}$. Psychosocial stress factors, such 
Table 6. Hierarchical multiple linear regression model for variables associated with stress at work among electric utility workers, São Paulo, 2005

\begin{tabular}{|c|c|c|c|c|c|c|}
\hline \multirow[t]{2}{*}{ Variables } & \multicolumn{2}{|c|}{ Univariate model } & \multicolumn{4}{|c|}{ Multiple model } \\
\hline & $\beta$ & $p$ & $\beta$ & $\mathrm{IC}_{95 \%}(\beta)$ & $p$ & $\mathrm{r}^{2} \mathrm{a}$ \\
\hline \multicolumn{7}{|c|}{ Socio-demographic features } \\
\hline Sex (male) & 0.135 & 0.248 & 0.133 & {$[-0.115,0.382]$} & 0.292 & 0.004 \\
\hline Age & 0.007 & 0.109 & 0.041 & {$[-0.005,0.013]$} & 0.356 & \\
\hline Marital status (married/living with a partner) & -0.154 & 0.045 & -0.120 & {$[-0.281,0.041]$} & 0.144 & \\
\hline Educational level (college graduation) & 0.007 & 0.924 & 0.020 & {$[-0.140,0.179]$} & 0.808 & \\
\hline \multicolumn{7}{|c|}{ Lifestyles* } \\
\hline Physical activity & -0.052 & 0.044 & -0.060 & {$[-0.112,-0.007]$} & 0.025 & 0.022 \\
\hline Smoking habits & 0.023 & 0.418 & 0.003 & {$[-0.057,0.064]$} & 0.911 & \\
\hline Alcohol consumption & 0.011 & 0.146 & 0.010 & {$[-0.007,0.026]$} & 0.249 & \\
\hline Body mass index $\left(\mathrm{kg} / \mathrm{m}^{2}\right)$ & 0.022 & 0.011 & 0.016 & {$[-0.002,0.034]$} & 0.074 & \\
\hline \multicolumn{7}{|c|}{ Occupational features** } \\
\hline Work sector & 0.058 & 0.314 & 0.004 & {$[-0.294,0.287]$} & 0.979 & 0.038 \\
\hline Job title & 0.019 & 0.584 & 0.104 & {$[-0.163,0.372]$} & 0.444 & \\
\hline Shift work & 0.015 & 0.302 & 0.187 & {$[-0.097,0.471]$} & 0.197 & \\
\hline Job content & 0.005 & 0.952 & -0.394 & {$[-0.840,0.052]$} & 0.084 & \\
\hline Time on the job (years) & 0.009 & 0.033 & 0.010 & {$[-0.003,0.024]$} & 0.135 & \\
\hline Monthly income & -0.027 & 0.358 & -0.147 & {$[-0.241,-0.054]$} & 0.002 & \\
\hline
\end{tabular}

*Adjusted by socio-demographic features.

**Adjusted by socio-demographic features and lifestyles.

Table 7. Association analysis between stress at work and health status among electric utility workers, São Paulo, 2005

\begin{tabular}{|c|c|c|c|}
\hline Dimension & $\mathrm{N}$ & $\mathrm{r}$ & $p$ \\
\hline \multicolumn{4}{|c|}{ Physical component } \\
\hline Physical functioning & 469 & -0.25 & $<0.001$ \\
\hline Role-physical & 473 & -0.27 & $<0.001$ \\
\hline Bodily pain & 473 & -0.33 & $<0.001$ \\
\hline General health & 472 & -0.32 & $<0.001$ \\
\hline \multicolumn{4}{|c|}{ Mental component } \\
\hline Vitality & 474 & -0.39 & $<0.001$ \\
\hline Social functioning & 474 & -0.34 & $<0.001$ \\
\hline Role-emotional & 473 & -0.25 & $<0.001$ \\
\hline Mental health & 474 & -0.48 & $<0.001$ (S) \\
\hline
\end{tabular}

(S) $=$ Spearman's correlation coefficients.

as lack of time, low motivation or financial difficulties may hamper the practice of physical activities, particularly among workers having a lower educational level or among those occupying lower positions in the hierarchical ladder ${ }^{31)}$. Tasks involving a high level of stress and poor control upon the work performed are associated with a lower level of physical activity 33,34 .

The present study also found that a reduction in income was associated with an increase in the level of stress at work. High income level, career opportunities and appre- ciation are the rewards expected. When there is no balance between the effort undertaken and the reward received, negative feelings may be triggered as a response to stress ${ }^{29,32)}$. Also, low income often associated with other negative factors like increased job insecurity, irregular working hours, occupational hazards and low work control, that can enhance their mutual negative effects, increasing stress at work and its harmful consequences ${ }^{17}$.

\section{Association between stress at work and health status}

In this studied population the stress at work was associated with all of the physical and mental health dimensions. The results point to the negative effects of stress upon health status. The association between stress and health has been consistently demonstrated, and evidence shows that stress at work gives a substantial negative contribution to workers' physical diseases and mental disorders $\left.^{2}, 3,18,19,29,32\right)$.

Exposure to work stressors result in non-specific reaction mechanisms generating negative mental and physiological responses, precursors of diseases, and can evolve to decreased well being, health symptoms and medical outcomes $^{1,35)}$. The SF-36 scales do not evaluate or identify specific health disturbances or diseases. It shows the perception of intermediate responses, such as changes in functioning and wellbeing, due to stress exposure, having the potential to anticipate health deterioration ${ }^{14,15)}$. 
It was observed weak correlations between stress at work and health dimensions. This is an indication of other factors mediating this process. In spite of it, physical as well as mental components showed statistical significance. These results are compatible with reported diseases by the study population. Former analyses based on the same set of data obtained from the present study and reported elsewhere ${ }^{5}$ showed that prevailing diseases reported by workers were mild emotional disorders $(8 \%)$ and musculoskeletal disorders (ranging from $3.2 \%$ to $13.7 \%)$.

In the last decades several studies investigating the association existing between health and stressing agents present in the work psychosocial environment have been published $^{3,18,19)}$. Longitudinal studies showed that regardless of individual characteristics, stressors at work prevail in the determination of mental health ${ }^{29}$. There is consistent evidence that an increase in physical and mental demands at work combined with a reduction in control over work, as well as great efforts combined with low rewards are conditions that favor the generation of common mental disorders, such as anxiety and depres$\operatorname{sion}^{18,29) \text {. }}$

The performed activities by the study population at work involved physical and mental demands, in some situations requiring moderate or intense physical efforts and/or constant exposure performed by blue collar electrical workers and white collar computer workers ${ }^{4-7)}$. The musculoskeletal disorders and associated pains may be related with the above mentioned working conditions, and can explain the association between physical dimensions of SF-36 and stress at work.

\section{Final comments}

The present study enabled us to characterize stress at work among electrical workers, its associated factors, as well as their associations with health status. The external validity of this study can be extended for workers of electrician companies having similar characteristics regarding demographic, working conditions and work organization.

Although the levels of perceived stress aren't considered too high, in view of the effects deriving from continuous exposure, we suggest the implementation of measures aiming to improve the work organization and the psychosocial environment, so that worker's needs and expectations are balanced with work demands. Such measures should address the factors identified as the major sources of stress. Special attention should be given to remuneration and practice of physical activity, which was also associated with stress at work, independently of any other variable.

The alcohol intake and overweight/obesity were not significantly associated with stress at work, and it may be due to the ceiling effect of their results distribution. In spite of this, they can be considered health risk factors and so it is necessary to implement intervention measures to control mentioned factors as well as to conduct a careful assessment of the nutritional status.

Considering the limitations of the cross-sectional study design and the scarcity of studies on health and stress among electrical workers, new studies should be carry out, ideally under a design that would allow causal relationships and to evaluate the results of the implemented measures for controlling stress at work.

\section{Acknowledgements}

Frida Marina Fischer is supported by CNPq (Process №.307919/2006-4; grant for productivity).

\section{References}

1) European Commission (2000) Guidance on WorkRelated Stress. Spice of Life, or Kiss of Death? Office for Official Publications of the European Commission, Luxembourg.

2) Kompier MAJ (2006) New systems of work organization and workers' health. Scand J Work Environ Health 32, 421-30.

3) Härmä M, Kompier MAJ, Vahtera J (2006) Work-related stress and health - risks, mechanisms and countermeasures. Scand J Work Environ Health 32, 413-9.

4) Nogueira VA (1999) Reestruturação do Setor Elétrico: um estudo qualitativo das condições de trabalho e saúde dos eletricitários frente à privatização da CERJ Master Thesis. Escola Nacional de Saúde Pública, Rio de Janeiro. http://portalteses.cict.fiocruz.br/pdf/FIOCRUZ/ 1999/nogueiravam/capa.pdf. Accessed July 4, 2007.

5) Martinez MC, Latorre MRDO (2008) Saúde e capacidade para o trabalho de eletricitários do Estado de São Paulo. Ciênc Saúde Coletiva 13,1061-73 (in Portuguese).

6) Batra PE, Ioannides MG (2001) Electric accidents in the production, transmission, and distribution of electric energy: a review of the literature. Int J Occup Safety Ergonomics 7, 285-307.

7) Levya GV, Elio MN, Arellano OL (2005) La producción de energía eléctrica y la salud de los trabajadores. Salud trab (Maracay) 13,19-36 (in Spanish).

8) Broadbent DE, Broadbent MHP, Male JC, Jones MR (1985) Health of workers exposed to electric fields. $\mathrm{Br}$ J Ind Med 42, 75-84.

9) Chevalier A, Sourques M, Coing F, Dab W, Lambrozo J (1999) Absenteeism and mortality of workers exposed to electromagnetic fields in the French Electricity Company. Occup Med 49, 571-24.

10) Johansen C (2004) Electromagnetic fields and health effects -epidemiologic studies of cancer, diseases of central nervous system and arrhythmia-related heart dis- 
ease. Scand J Work Environ Health 30(suppl 1), 1-80.

11) Florindo AA, Latorre MRDO (2003) Validation and reliability of the Baecke questionnaire for the evaluation of habitual physical activity in adult men. Rev Bras Med Esporte 9, 129-35.

12) Babor TF, Higgins-Biddle JC, Saunders JB, Monteiro MG (2001) AUDIT —cuestionario de identificación de los transtornos debidos al consumo de alcohol: pautas para su utilización en atención primaria, Organización Mundial de la Salud, Ginebra (in Spanish).

13) WHO - World Health Organization. The WHO Global Database on Body Mass Index (BMI) 2006. http://www. who.int $/ \mathrm{bmi} /$ index.jsp? introPage $=$ intro_ $1 . \mathrm{html}$. Accessed January 29, 2008.

14) Ware JE, Kosinski M (2001) Interpreting SF-36 summary health measures: a response. Qual Life Res 10, $405-13$.

15) Ciconelli RM, Ferraz MB, Santos W, Meirão I, Quaresma MR (1999) Tradução para a língua portuguesa e validação do questionário genérico de avaliação de qualidade de vida SF-36 (Brasil SF-36). Rev Bras Reumatol 39, 143-50 (in Portuguese).

16) Paschoal T, Tamayo A (2004) Validação da escala de estresse no trabalho. Estud Psicol (Natal) 9, 45-52 (in Portuguese).

17) Houtman I, Jettinghoff K, Cedilb L (2007) A model on work-related stress. In: Raising awareness of stress at work in developing countries: a modern hazard in a traditional working environment: advice to employer and worker representatives, 15-22, World Health Organization, Geneva.

18) Michie S, Williams S (2003) Reducing work related psychological ill health and sickness absence: a systematic literature review. Occup Environ Med 60, 3-9.

19) Karasek R, Theorell T (1990) Healthy work: stress, productivity, and the reconstruction of working life. In: Health, productivity and work life, 1-30. Basic Books, USA.

20) Fowler Jr DJ (1990) Nonresponse: implementing a sample design. In: Survey Research Methods, 45-60, SAGE, California.

21) Pereira JCR (1990) Processamento e análise de variáveis qualitativas. In: Análise de dados qualitativos: estratégias metodológicas para as ciências da saúde humanas e sociais, 77-100, EDUSP, São Paulo (in Portuguese).

22) Klingemann H (2001) Alcohol and its social conse- quences - the forgotten dimension. World Health Organization/Regional Office for Europe, Copenhagen.

23) WHO -World Health Organization (2007) WHO Expert Committee on problems related to alcohol consumption. WHO, Geneva.

24) Neves DP (2004) Alcoolismo: acusação ou diagnóstico? Cad Saúde Pública 20, 7-36.

25) Obot IS, Room R (2005) Alcohol, gender and drinking problems: perspectives from low and middle income countries. World Health Organization/Department of Mental Health and Substance Abuse, Geneva.

26) Bloomfield K (2005) Introduction. In: Bloomfield K, Allamani A, Beck F, Begrma KH, Csemy L, EisenbachStang I et al. Gender, culture and alcohol problems: a multi-national study, 11-22, Charité Universitätsmedizin/Institute for Medical Informatics, Biometrics \& Epidemiology, Berlin.

27) Bagust A, Welley $T$ (2000) An alternative to body mass index for standardizing body weight for stature. J Q Med 93, 589-96.

28) Cervi A, Franceschini SCC, Priore SE (2005) Análise crítica do uso do índice de massa corporal para idosos. Rev Nutr Campinas 18, 765-75.

29) Stansfeld S, Candy B (2006) Psychosocial work environment and mental health - a meta-analytic review. Scand J Work Environ Health 32, 443-62.

30) Pohjonen T, Ranta R (2001) Effects of worksite physical exercise intervention on physical fitness, perceived health status, and work ability among home care workers: five-years follow-up. Prev Med 32, 465-75.

31) Mello MT, Boscolo RA, Esteves AM, Tufik S (2005) O exercício físico e os aspectos biopsicológicos. Rev Bras Med Esporte 11, 203-7 (in Portuguese).

32) Siegrist J, Rödel A (2006) Work stress and health risk behavior. Scand J Work Environ Health 32, 473-81.

33) Kouvonen A, Kivimäki M, Elovainio $M$, Virtanen $M$, Linna A, Vahtera J (2005) Job strain and leisure-time physical activity in female and male public sector employees. Prev Med 41, 532-9.

34) Wemme KM, Rosvall M (2005) Work related and nonwork related stress in relation to low leisure time physical activity in a Swedish population. J Epidemiol Community Health 59, 377-9.

35) Levi L (1997) Psychosocial environmental factors and psychosocially mediated effects of physical environmental factors. Scand J Work Environ Health 23, 47-52. 